\begin{tabular}{|c|c|}
\hline 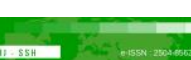 & Malaysian Journal of Social Sciences and Humanities (MJSSH) \\
\hline Malaysian Journal of & Volume 5, Issue 11, November 2020 \\
\hline (MJ - SSH) & e-ISSN : 2504-8562 \\
\hline & $\begin{array}{l}\text { Journal home page: } \\
\text { www.msocialsciences.com }\end{array}$ \\
\hline
\end{tabular}

\title{
Factors Influencing Mathematics Performance among Secondary School Students
}

\author{
Nur Syaliza Hanim Che Yusof', Idari Ismail'1, Nor Fatihah Abd Razak', Fatasya Izliana Ibrahim1, \\ Naqibatunnazakat Mohd Pu'ad'1, Nur Syahira Ramali' \\ 1Universiti Teknologi MARA (UiTM)
}

Correspondence: Nur Syaliza Hanim (syalizahanim@gmail.com)

\begin{abstract}
Mathematics is one of the subject that continuously learn from kindergarten up to university level. From simple learning numbers until the complex level, mathematics is one of core subject that need to be mastered in Malaysia. This study aims to identify significant factors that influencing mathematics performance among secondary school in East Coast areas. The factors that being studies are learning style, self-motivation and study environment. Besides, some of demographic variables also being studied. There are 223 students from four different secondary schools in East Coast area were involved as respondents for this study. Questionnaire was given and Multiple Linear Regression was applied. It was found that self-motivation is a significant factor that influences mathematics performance. This shows that student who highly motivated will perform better in mathematics subject.
\end{abstract}

Keywords: mathematics, secondary school, multiple linear regression

\section{Introduction}

Mathematics is a must subject for all students to take since primary school until secondary school as stated by Malaysia Education System. In university level, mathematics is also compulsory for some courses. Mathematics is not only to be learned in the school but students should also be able to apply mathematical ideas later on in their life. Learning mathematics is a continuous process and not limited to the education purpose only. It is also a body of knowledge in the area of science and technology. Besides, it also contributes to the purposes of general education where children become useful members of the community.

Students will learn mathematics well when they can construct their own understanding on how mathematics work and it requires them to examine, represent, transform, solve, apply, prove and communicate. Unfortunately, since mathematics had too much formula and unfamiliar symbol, most of students were not performed in mathematics as they saw it was a difficult subject among the rest. Apart from that it will affect their overall academic performance. This supported by SPM 2019 results where mathematics subject recorded a decline in performance in 2019 compared to 2018 (Mohamed Radhi, $\mathrm{N}$. A., 5 March 2020). Main objective for this study is to determine the significant factor (learning style, self-motivation and study environment) that contributed the most towards academic performance in mathematics among secondary school students. Besides, gender difference in mathematics performance also being studied. 


\section{Literature Review}

Mathematical related subject is one of the most core and difficult subject for secondary school student to score especially additional mathematics. The study about mathematical subject is established in order to produce a multitasking and high competent individual who able to manipulate and apply knowledge of mathematics in daily life. This individual has important role and responsible in making effective decision and able to solve problem occur in everyday life (Effandi, Normalizam, Nuramalina \& Ayuerlina 2012).

For mathematician who expert in this subject find that computation in mathematics is necessary tool for comprehending structures, relationship and patterns of mathematical concepts. Therefore, mathematics is one of the methods to find solution to solve complicated problem in real life. This perspective has gained more attention with rapid advancement in information and communication technologies nowadays. Apart from that, it is necessary for the people to have knowledge in mathematical subjects in order to become a successful individual in this information technologies era. So, started from student, they need to be well equipped with higher order mathematical knowledge (Tuncay \& Omar, 2009).

Motivation plays an important role in determining students' academic performance. Pintrich \& Schunk (2006) defined motivation toward learning is a process that encourages individual to learn and maintains interest in the learning element. The study done by Moenikia \& Zahed-Babelan (2010) found that there is a relationship between motivation toward learning and mathematics performances in high school students. While, Tuncay \& Omar (2009) found that the level of motivation is affected by perception and belief; perceived learning abilities and competencies. The study also found out that there is significant difference between motivation and grades.

Besides motivation, Lamb \& Fullarton (2002) stated that classroom atmosphere is believed to influence student's performance. A good environment will positively effect on student's achievement. A good environment is specified to include temperature, lightning and noise control (Murugan \& Rajoo, 2013). Shamaki (2015) also found that there is significant difference between mean performance of students who taught in an ideal learning environment and students who taught in a dull learning environment. Learning style is generally defined as a students' preferred way of learning. Thus, understanding learning style may generate different way of perception in learning. Ismail \& Awang (2008) found out that student mathematics achievement significantly increased with their aspirations, perceptions of being safe in the school, self-confidence in mathematics and time spent on homework.

\section{Methodology}

Participants for this study is 223 Form 5 students from four different secondary schools in East Coast area. The data was collected using self-administered questionnaire. The questionnaire consists of four sections which are demographic profiles, learning styles, self-motivation and study environment. Dependent variable is mathematics test score. Multiple Linear Regression analysis was employed to determine the significant factors that influence mathematics performance. While, Independent $t$-test was employed to identify significance difference in mathematics performance between gender.

\section{Result}

Table 1 shows the descriptive findings for demographic profile. Out of 223, 122 are female students while the rest are male students. However, the distribution of gender almost half. Besides that, most of the students are going to mathematics tuition where extra classes is taken for mathematics subject. Majority of them also spent between one to two hours studying mathematics in a week and only few of them spent more than 2 hours for studying mathematics. 
DOI: https://doi.org/10.47405/mjssh.v5i11.533

Table 1: Descriptive of Demographic Profile

\begin{tabular}{ccc}
\hline Variable & Frequency & Percentage (\%) \\
\hline Gender & 101 & 45.3 \\
Male & 122 & 54.7 \\
Female & & \\
Mathematics Tuition & 123 & 55.2 \\
Yes & 100 & 44.8 \\
No & & \\
Study hour & 93 & 41.7 \\
$<1$ hour & 120 & 53.8 \\
$1-2$ hours & 10 & 4.5 \\
$>2$ hours & &
\end{tabular}

Table 2 shows that significant value is 0.722 which is greater than critical value $(\alpha=0.05)$. The $95 \%$ confidence interval value is lies between -4.597 and 6.628. Thus, this indicates that there is no significant difference in the mean of mathematics performance between male and female students.

Table 2: Independent t-Test Result

\begin{tabular}{lllll}
\hline & T-test & Sig. & \multicolumn{2}{l}{$\begin{array}{l}\text { 95\% Confidence Interval for } \\
\text { difference }\end{array}$} \\
\hline $\begin{array}{l}\text { Student performance in } \\
\text { mathematics subject }\end{array}$ & 0.357 & 0.722 & -4.597 (lower) & 6.628 (upper) \\
\hline
\end{tabular}

Multiple Linear Regression result is presented in Table 3 where its show the coefficients of the model. From the significant values, it shows that only self-motivation $(<0.0001)$ is significant to determine mathematics performance. While other variables which are learning style $(0.081)$ and study environment (0.393) not significant.

Table 3: Table of Coefficients

\begin{tabular}{|c|c|c|c|c|c|}
\hline & \multicolumn{2}{|c|}{$\begin{array}{l}\text { Unstandardized } \\
\text { Coefficients }\end{array}$} & \multirow{2}{*}{$\begin{array}{c}\begin{array}{c}\text { Standardized } \\
\text { Coefficients }\end{array} \\
\text { Beta }\end{array}$} & \multirow[t]{2}{*}{$\mathbf{t}$} & \multirow[t]{2}{*}{ sig } \\
\hline & $\mathbf{B}$ & Std. Error & & & \\
\hline Constant & 3.375 & 0.742 & & 4.546 & $<0.0001$ \\
\hline Learning style & -0.196 & 0.112 & -0.129 & -1.752 & 0.081 \\
\hline Self-motivation & 0.615 & 0.089 & 0.500 & 6.944 & $<0.0001$ \\
\hline Study environment & -0.103 & 0.121 & -0.065 & -0.855 & 0.393 \\
\hline
\end{tabular}

\section{Conclusion}

This study was carried out to identify the significant factors that influencing mathematics performance. Based on the findings, it shows that mathematics performance does not influence by different between gender. This indicates that neither male or female students may perform better in mathematics. For variables learning style, self-motivation and study environment, only self-motivation gives a significant impact on mathematics performance. This shows that high motivated students may performs better in mathematic subject rather than those students who have low motivation. The result of this study supported by Suarez-Alvarez, Fernandez-Alonso \& Muniz (2014) study done using Structural Equation Modeling where motivation is statistically significant correlation with academic performance. 


\section{References}

Effandi, Z., Normalizam, M. Z., Nur Amalina, A. \& Ayu Erlina (2012). Mathematics Anxiety and Achievement among Secondary School Students. American Journal of Applied Sciences. 9 (11): 1761-1765.

Ismail, N. A., \& Awang, H. (2008). Mathematics achievement among Malaysian students: what can they learn from Singapore. Retrieved from hppt://www.ccnet .org /journal .html.

Lamb, S., \& Fullarton, S. (2002). Classroom and school factors affecting mathematics achievement: A comparative study of Australia and the United States using TIMSS. Australian Journal of education, 46(2), 154-171.

Moenikia, M., \& Zahed-Babelan, A. (2010). A study of simple and multiple relations between mathematics attitude, academic motivation and intelligence quotient with mathematics achievement. Procedia-Social and Behavioral Sciences, 2(2), 1537-1542.

Mohamed Radhi, N. A. (2020, March 5). SPM 2019 results: Better National Average Grade score. New Straits Times. https://www.nst.com.my/news/nation/2020/03/571877/spm-2019-results-betternational-average-grade-score.

Murugan, A. \& Rajoo, L. (2013). Students' Perceptions of Mathematics Classroom Environment \& Mathematics Achievement: A Study in Sipitang, Sabah, Malaysia. Proceeding of the International Conference on Social Science Research, ICSSR 2013 (E-Isbn 978-967- 11768-18). 4-5 June 2013, Penang, Malaysia. Organized By Worldconferences.Net

Pintrich, P. R., \& Schunk, D. H. (2006). Motivation in education contexts: Theory, research and applications. Pearson Education.

Shamaki, T. A. (2015). Influence of Learning Environment on Students' Academic Achievement in Mathematics: A Case Study of Some Selected Secondary Schools in Yobe State-Nigeria. Joumal of Education and Practice, 6(34), 40-44.

Suárez-Álvarez, J., Fernández-Alonso, R., \& Muñiz, J. (2014). Self-concept, motivation, expectations, and socioeconomic level as predictors of academic performance in mathematics. Learning and Individual Differences, 30, 118-123.

Tuncay ,S.,Omar,A. (2009). Identifying Factors Affecting the Mathematics Achievement of Students for Better Instructional Design. International Journal of Instructional Technology and Distance Learning, 6(12). 